\title{
Ecological consequences of hunting in Atlantic forest patches, São Paulo, Brazil
}

\author{
L. Cullen Jr, E. R. Bodmer and C. Valladares-Padua
}

\begin{abstract}
This paper evaluates the ecological consequences of hunting by comparing mammalian densities, biomass, relative energy consumption and community structure between sites with different levels of hunting pressure. Hunting is carried out mainly by colonists who farm on the edge of Atlantic forest fragments in the State of São Paulo, Brazil. Mammals were studied over a period of 18 months, along $2287 \mathrm{~km}$ of line transects. Transects were distributed among two protected sites, one slightly hunted site and two heavily hunted sites. Tapirs, the two peccary species, brocket deer, armadillos and agoutis are preferred by hunters in the region. Primates are not hunted in the region. Hunting has affected community structure, with ungulates domin-
\end{abstract}

\section{Introduction}

Overhunting reduces the populations of the specific species hunted, changes the composition of animal communities, and influences relationships of predation and competition (Peres, 1990; Bodmer et al., 1997). Overhunting also causes ecological changes in habitat through altered interactions of seed dispersal, seed predation and folivory. Terborgh (1988) has shown evidence that the 'big things' such as the large herbivores play an important role in the structure and dynamics of tropical forests. Overhunting, therefore, not only reduces populations of specific species, but causes landscape-level changes in habitats and faunal assemblages that must be considered for wildlife conservation and management.

Measuring ecological changes caused by overhunting is difficult and cumbersome because of the vast number of ecological interactions that can result in countless different outcomes. However, the ecological impact of overhunting can be estimated through measures of density and biomass. Density looks at variation in numbers of individuals, and biomass provides insights

\footnotetext{
Laury Cullen Jr. and C. Valladares-Padua IPÊ-Instituto de Pesquisas Ecológicas, Parque Estadual do Morro do Diabo, C.P. 91, Teodoro Sampaio, SP. 19280-000, Brazil. E-mail: Icullen@stetnet.com.br
}

Richard E. Bodmer (corresponding author) Durrell Institute of Conservation and Ecology, University of Kent, Canterbury, CT2 7NS, UK. E-mail: r.bodmer@ukc.ac.uk

Revised manuscript accepted for publication 16 November 2000 ating mammalian biomass at protected sites and primates dominating at hunted sites. This has caused an ecological inversion in the hunted areas of the Atlantic forests. In Amazonian regions of the Neotropics hunting is more evenly distributed among primates, large rodents, and ungulates and has resulted in an opposite inversion, with hunted sites having lower primate biomass. Atlantic forests are very susceptible to the possible ecological imbalances induced by hunting by humans, and this must be considered for management and conservation programmes.

Keywords Atlantic Forest, biomass, Brazil, density, hunting, mammals.

to the relative importance (i.e. dominance), trophic structure and ecological impact (i.e. food consumption and nutrient cycling) of animal populations (Eisenberg, 1980).

In the Neotropics most studies on density and biomass of non-flying mammals are in areas dominated by evergreen forests (Eisenberg \& Thorington, 1973; Emmons, 1984; Janson \& Emmons, 1990; Peres, 1990). Studies in semideciduous areas of the Neotropics show lower arboreal biomass of mammals than evergreen forests, presumably because drier semideciduous habitats have periods of seasonal drought, whereas evergreen forests have less seasonal variation in plant productivity (Eisenberg et al., 1979; Eisenberg, 1980; Schaller, 1983). The semideciduous Atlantic forests should show similar patterns to other semideciduous areas, and have a lower biomass of arboreal mammals and a higher biomass of terrestrial mammals such as ungulates and large rodents.

Ungulates are heavily hunted and even extirpated in some Atlantic forest fragments (Cullen, 1997; Cullen et al., 2000), and hunting might be causing ecological changes by altering the mammalian biomass in hunted fragments. To evaluate the ecological impact of this overhunting we studied the density and biomass differences between hunted and protected sites. We examined how hunting affects density and biomass of large- and medium-sized mammals in the semideciduous forests of the Atlantic forests. Mammals were censused in five forest fragments during an 18-month period. 


\section{Methods}

\section{Study sites}

From May 1995 to December 1996 five forest fragments were studied in the Plateau (Mata de Planalto) range in the interior of the State of São Paulo, Brazil (Fig. 1). Three of the sites were in the western part of the state (Fazenda Tucano, Fazenda Mosquito and Morro do Diabo State Park) and two sites were in the central part (Fazenda Rio Claro and Caetetus Ecological Station). The greatest distance between sites was $300 \mathrm{~km}$.

Quantitative hunting pressure was not recorded during this study. As an alternative we used a series of measures that were recorded during the censuses, including number of shots heard, number of active hunting platforms seen, number of hunting dogs seen and number of hunters encountered. These measures were used to define areas as 'protected', 'slightly hunted' and 'heavily hunted'. The protected sites were Morro do Diabo State Park and Caetetus Ecological Station, the slightly hunted site was Fazenda Mosquito, and the heavily hunted sites included Fazenda Rio Claro and Fazenda Tucano (Table 1).
Plateau forests are a transitional ecosystem, bordered by tropical evergreen broadleaf forest to the east, which originally covered the Atlantic coastline, and the dry cerrado vegetation to the north and west ( $\mathrm{Ab}^{\prime}$ Saber, 1977). Cerrado is a tall dense semideciduous xeromorphic savanna vegetation (Baitello et al., 1988). The region is characterized by a pronounced dry season with annual precipitation averaging between 1200 and $1260 \mathrm{~mm}$ of which 30 per cent falls between April and September (Valladares-Padua, 1987, 1993). Most of the emergent trees lose their leaves during the dry months (Hueck, 1972). The region is also known for its general nutrient-poor sand soils (Setzer, 1949).

\section{Density and biomass estimates}

Densities of species were estimated using censuses along line transects (Glanz, 1982; Emmons, 1984). Four to eight transects were placed in each fragment. Forest fragments are defined here as continuous blocks of forest surrounded by open pastureland or other types of agricultural lands. Each transect ranged from 0.5 to $8 \mathrm{~km}$ in length and was surveyed several times. The cumulative distance censused at each fragment ranged from 161 to $618 \mathrm{~km}$ (mean $=381 \mathrm{~km})$, with a total of

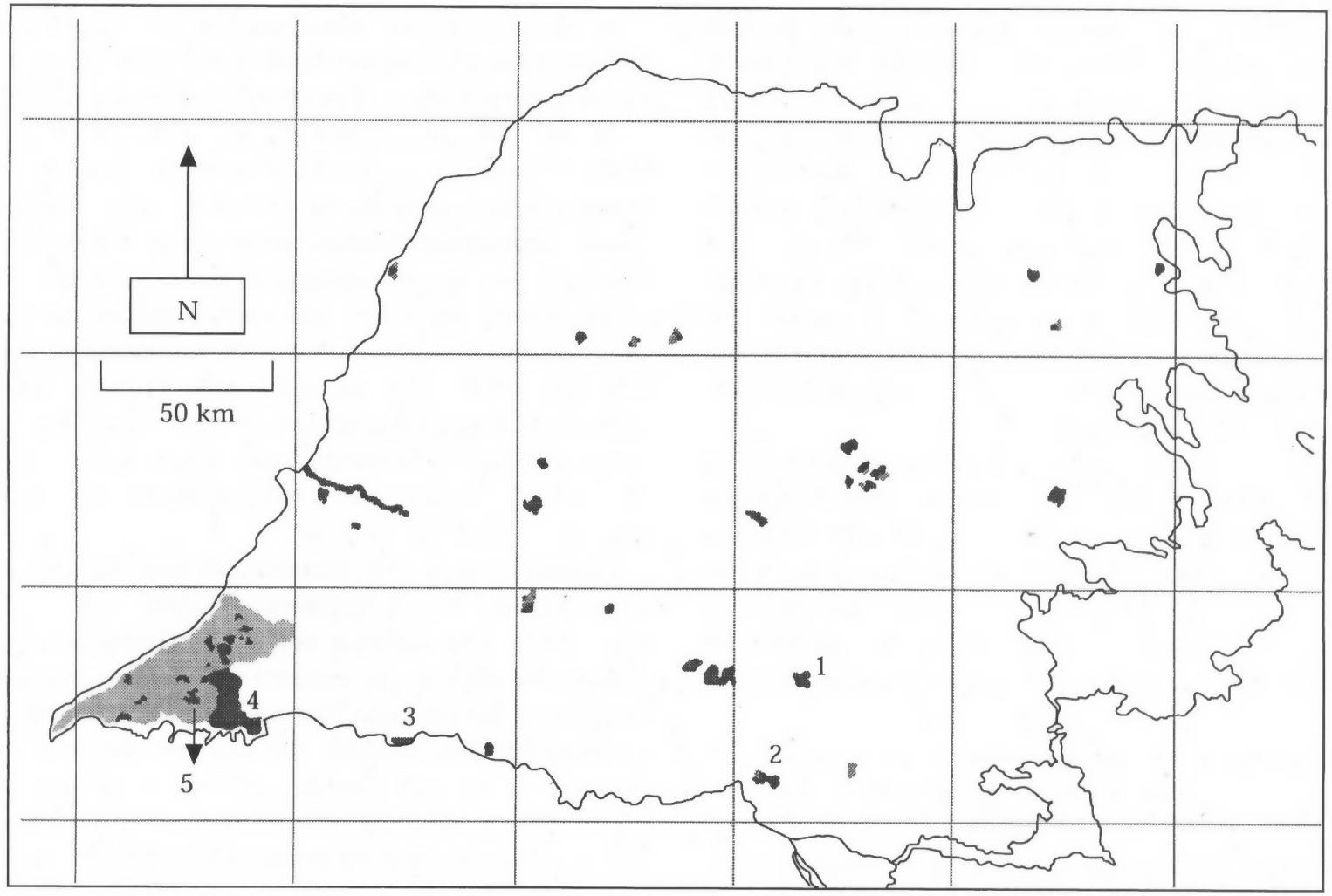

Fig. 1 Map of forest fragments in the Plateau region of São Paulo state, Brazil. The five sites used in this study are labelled as: 1 Caetetus Ecological Station, 2 Fazenda Rio Claro, 3 Fazenda Mosquito, 4 Morro do Diabo State Park and 5 Fazenda Tucano. 
Table 1 General characteristics and qualitative measures to assess hunting in the five study sites.

\begin{tabular}{|c|c|}
\hline General characteristics & Assessment of hunting \\
\hline \multicolumn{2}{|l|}{ Morro do Diabo State Park $(35,000$ ha $)$} \\
\hline Established 1985 & Protected from hunters \\
\hline Semideciduous Atlantic forest & 0 gunshots heard during censuses \\
\hline $1200 \mathrm{~mm}$ annual precipitation & 0 hunting platforms found during censuses \\
\hline 50 per cent mature forest, $20-30 \mathrm{~m}$ canopy height & 0 encounters with hunters during censuses \\
\hline 50 per cent undisturbed forest, $30-40 \mathrm{~m}$ canopy height & 0 hunting dogs seen during censuses \\
\hline \multicolumn{2}{|l|}{ Caetetus Ecological Station (2178 ha) } \\
\hline Established 1977 & Protected from hunters \\
\hline Semideciduous Atlantic forest & 0 gunshots heard during censuses \\
\hline $1260 \mathrm{~mm}$ annual precipitation & 0 hunting platforms found during censuses \\
\hline 50 per cent mature forest, $20-30 \mathrm{~m}$ canopy height & 0 encounters with hunters during censuses \\
\hline 50 per cent undisturbed forest, $30-40 \mathrm{~m}$ canopy height & 2 hunting dogs seen during censuses \\
\hline \multicolumn{2}{|l|}{ Fazenda Mosquito (2100 ha) } \\
\hline Private cattle ranch & Slightly hunted \\
\hline Semideciduous Atlantic forest & 3 gunshots heard during censuses \\
\hline $1200 \mathrm{~mm}$ annual precipitation & 3 hunting platforms found during censuses \\
\hline 50 per cent mature forest, $20-30 \mathrm{~m}$ canopy height & 2 encounters with hunters during censuses \\
\hline 50 per cent undisturbed forest, $30-40 \mathrm{~m}$ canopy height & 1 hunting dog seen during censuses \\
\hline \multicolumn{2}{|l|}{ Fazenda Tucano (2000 ha) } \\
\hline Private cattle ranch & Heavily hunted \\
\hline Semideciduous Atlantic forest & 5 gunshots heard during censuses \\
\hline $1200 \mathrm{~mm}$ annual precipitation & 5 hunting platforms found during censuses \\
\hline 50 per cent mature forest, $20-30 \mathrm{~m}$ canopy height & 8 encounters with hunters during censuses \\
\hline 50 per cent undisturbed forest, $30-40 \mathrm{~m}$ canopy height & 4 hunting dogs seen during censuses \\
\hline \multicolumn{2}{|l|}{ Fazenda Rio Claro (1700 ha) } \\
\hline Private cattle ranch & Heavily hunted \\
\hline Semideciduous Atlantic forest & 5 gunshots heard during censuses \\
\hline $1260 \mathrm{~mm}$ annual precipitation & 4 hunting platforms found during censuses \\
\hline 50 per cent mature forest, $20-30 \mathrm{~m}$ canopy height & 12 encounters with hunters during censuses \\
\hline 50 per cent undisturbed forest, $30-40 \mathrm{~m}$ canopy height & 4 hunting dogs seen during censuses \\
\hline
\end{tabular}

$2287 \mathrm{~km}$ censused. Each forest fragment was surveyed on average 5 days per month and sampling effort was about 70 days for each site during the 18-month study. Transects were censused between 06.00 and $10.00 \mathrm{hrs}$ and again from 15.00 to $19.00 \mathrm{hrs}$. Sampling effort was greatest for diurnal species, but also included crepuscular and some nocturnal animals. Censuses were done by walking slowly (approximately $1 \mathrm{~km}$ per hour, following Emmons, 1984) and stopping briefly every 50-100 m. The time, species, location along the trail, group size, sighting angle and sighting distance from the trail were recorded for each sighting. For social animals the group was the sample unit and the first animal seen was used as the sighting distance. Only accurate counts were used to estimate average group size. Densities were estimated using the 'DISTANCE sampling' method and computer software developed by Buckland et al. (1993) and Laake et al. (1994).

Line transect sampling is currently the most common method used to estimate densities of large- and mediumsized Neotropical mammals (Peres, 1990, 2000; Bodmer et al., 1997; Hill \& Padwe, 2000). The reliability of line transects to estimate density depends largely on the sample size of observations (Burnham et al., 1980; Buckland et al., 1993; Wilson et al., 1996). All species were observed on more than 20 occasions, ranging from 23 for the lowland tapir to 285 for the brown capuchin monkey (Table 2). The number of observations per site were less than the species total, but were only less than 15 on a few occasions. We nevertheless included these smaller sample sizes, because our analyses are relative comparisons between sites.

Crude biomass was calculated for each species using the average body weight of adult individuals (BW) multiplied by the estimated densities of individuals (D) as ( $\mathrm{BW} \times \mathrm{D}=\mathrm{kg}$ per sq $\mathrm{km}$ ). Metabolic biomass was also calculated for each species using the average body weight of adult individuals raised to the 0.75 power $\left(\mathrm{BW}^{0.75}\right)$ and multiplied by the estimated individual densities (D) as ( $B W^{0.75} \times \mathrm{D}=\mathrm{kg}$ per sq $\mathrm{km}$ ). Mean body masses were taken from the literature (Robinson \& Redford, 1986), with the exception of peccaries and the black lion tamarin where data were available from the study sites. Percentage contribution $(\%)$ is the 
Table 2 Mammal species sighted and number of observations recorded during line transect sampling.

\begin{tabular}{lc}
\hline & $\begin{array}{c}\text { Number of } \\
\text { observations }\end{array}$ \\
\hline Lowland tapir (Tapirus terrestris) & 23 \\
White-lipped peccary (Tayassu pecari) & 25 \\
Collared peccary (Tayassu tajacu) & 52 \\
Brocket deer (Mazama spp.) & 33 \\
Azara's agouti (Dasyprocta azarae) & 119 \\
Nine-banded armadillo (Dasypus novencintus) & 40 \\
South American coati (Nasua nasua) & 37 \\
Guianan squirrel (Sciurus aestuans) & 76 \\
Brown capuchin monkey (Cebus appela) & 285 \\
Brown howler monkey (Allouata fusca) & 162 \\
\hline
\end{tabular}

relative contribution of a species to the total biomass of the large and medium body-sized mammalian community in each study site.

Metabolic biomass takes into consideration the relationship between body weight and metabolic rate (Peters, 1983). Metabolic biomass should reflect the relative ecological importance of species in terms of energy consumption. For this reason, we used metabolic biomass to compare the ecological impact of hunting between the study sites.

We recognize that there are possibly differences in the soils and structure of the forests between sites, which could cause distinct patterns of species densities between forest patches independent of hunting pressure. Local differences in soil and vegetation are important, although all of the patches were once part of the same continuous forest and have the same geological origins. Many of the wildlife species examined have large geographical ranges and broad ecological tolerances
(Eisenberg, 1980), therefore, we assumed that soil and habitat heterogeneity would not lead to gross differences in wildlife densities, and that local differences in hunting would override differences in habitat.

\section{Results}

\section{Density}

Density, crude biomass, and metabolic biomass of largeand medium-sized mammals varied between sites. Densities of lowland tapir and white-lipped peccary were greater in the protected sites, compared with the slightly hunted sites, and both species were extirpated from the heavily hunted sites (Table 3 ). Brocket deer had similar densities between the protected and slightly hunted sites and were rare in the heavily hunted sites. Collared peccary, Azar's agouti, the nine-banded armadillo, South American coati, and the Guianan squirrel all had considerable variation in their densities between sites and were often just as abundant in one of the heavily hunted sites as the protected sites. Likewise, the three primate species - brown capuchin monkey, brown howler monkey and black lion tamarin - did not show any consistent trend in their densities between the five sites and were often just as abundant in the heavily hunted sites as the protected sites.

\section{Crude biomass}

The protected sites had the greatest crude biomass of the large- and medium-sized mammals, with $646 \mathrm{~kg}$ per sq $\mathrm{km}$ at Morro do Diabo State Park and $600 \mathrm{~kg}$ per sq $\mathrm{km}$ at Caetetus Ecological Station (Table 4). The

Table 3 Density of large- and medium-sized mammals in the five study sites of the Plateau. Values are in individuals per sq $\mathrm{km}$.

\begin{tabular}{|c|c|c|c|c|c|}
\hline Species/sites & $\begin{array}{l}\text { Morro do Diabo } \\
\text { State Park } \\
\text { (Protected) }\end{array}$ & $\begin{array}{l}\text { Caetetus } \\
\text { Ecological Station } \\
\text { (Protected) }\end{array}$ & $\begin{array}{l}\text { Fazenda } \\
\text { Mosquito } \\
\text { (Slightly hunted) }\end{array}$ & $\begin{array}{l}\text { Fazenda } \\
\text { Tucano } \\
\text { (Heavily hunted) }\end{array}$ & $\begin{array}{l}\text { Fazenda } \\
\text { Rio Claro } \\
\text { (Heavily hunted) }\end{array}$ \\
\hline Lowland tapir & 0.41 & 0.47 & 0.30 & Extirpated & Extirpated \\
\hline White-lipped peccary & 6.94 & 6.30 & 3.60 & Extirpated & Extirpated \\
\hline Collared peccary & 5.67 & 6.41 & 0.81 & 2.21 & 5.63 \\
\hline Brocket deer & 1.13 & 1.82 & 1.75 & $\mathrm{P}$ & $\mathrm{P}$ \\
\hline Azara's agouti & 26.80 & $\mathrm{P}$ & 0.39 & 4.10 & 0.91 \\
\hline Nine-banded armadillo & 0.80 & 23.63 & 16.97 & 9.60 & $\mathrm{P}$ \\
\hline South American coati & 4.20 & 4.47 & 3.40 & 3.11 & 5.20 \\
\hline Guianan squirrel & 0.37 & 11.31 & 20.20 & 3.91 & 2.71 \\
\hline Brown capuchin monkey & 9.96 & 17.64 & 8.31 & 8.57 & 10.18 \\
\hline Brown howler monkey & 15.66 & $0.60^{d}$ & 36.30 & 10.91 & 16.27 \\
\hline Black lion tamarin & $2.66^{a}$ & 1.71 & $0.25^{b}$ & $1.00^{a}$ & $3.66^{c}$ \\
\hline
\end{tabular}

"Density estimates from Valladares-Padua (1993).

"Represents the density from the only five individuals translocated to the area in 1996.

${ }^{c}$ Density estimate from Valladares-Padua \& Cullen Jr (1992).

${ }^{d}$ Density estimate from the three groups known to occur in the area.

$\mathrm{P}=$ Present, but not seen during census. 
Table 4 Crude biomass (CB) estimates of large- and medium-sized mammals in the five study sites of the Plateau. Values are in $\mathrm{kg}$ per sq $\mathrm{km}$.

\begin{tabular}{|c|c|c|c|c|c|c|c|c|c|c|c|}
\hline \multirow[b]{2}{*}{ Species } & \multirow{2}{*}{$\begin{array}{l}\text { Mean } \\
\text { body } \\
\text { weight } \\
(\mathrm{kg})\end{array}$} & \multicolumn{2}{|c|}{$\begin{array}{l}\text { Morro do Diabo } \\
\text { State Park } \\
\text { (Protected) }\end{array}$} & \multicolumn{2}{|c|}{$\begin{array}{l}\text { Caetetus Ecolo- } \\
\text { gical Station } \\
\text { (Protected) }\end{array}$} & \multicolumn{2}{|c|}{$\begin{array}{l}\text { Fazenda Mos- } \\
\text { quito (Slighted } \\
\text { hunted) }\end{array}$} & \multicolumn{2}{|c|}{$\begin{array}{l}\text { Fazenda Tucano } \\
\text { (Heavily } \\
\text { hunted) }\end{array}$} & \multicolumn{2}{|c|}{$\begin{array}{l}\text { Fazenda Rio } \\
\text { Claro (Heavily } \\
\text { hunted) }\end{array}$} \\
\hline & & $\mathrm{CB}$ & $\%$ & CB & $\%$ & $\mathrm{CB}$ & $\%$ & $\mathrm{CB}$ & $\%$ & $\mathrm{CB}$ & $\%$ \\
\hline Lowland tapir & 148.95 & 61 & 9 & 70 & 11 & 44 & 8 & 0 & 0 & 0 & 0 \\
\hline White-lipped peccary & $31.67^{a}$ & 219 & 34 & 199 & 33 & 114 & 20 & 0 & 0 & 0 & 0 \\
\hline Collared peccary & $19.10^{a}$ & 108 & 16 & 122 & 20 & 15 & 3 & 42 & 21 & 107 & 39 \\
\hline Brocket deer & $21.72^{b}$ & 24 & 3 & 39 & 6 & 38 & 7 & $\mathrm{P}$ & $\mathrm{P}$ & P & $\mathrm{P}$ \\
\hline Azara's agouti & 2.84 & 76 & 11 & P & $\mathrm{P}$ & 1 & 0.1 & 11 & 5 & 2 & 1 \\
\hline Nine-banded armadillo & 3.54 & 2 & 0.4 & 83 & 14 & 60 & 10 & 34 & 16 & $\mathrm{P}$ & $\mathrm{P}$ \\
\hline South American coati & 3.88 & 16 & 2 & 15 & 2 & 13 & 2 & 12 & 6 & 20 & 7 \\
\hline Guianan squirrel & 0.38 & 0.1 & 0.02 & 4 & 0.7 & 7 & 1 & 1 & 0.7 & 1 & 0.3 \\
\hline Brown capuchin monkey & 3.44 & 34 & 5 & 60 & 10 & 29 & 5 & 30 & 14 & 35 & 13 \\
\hline Brown howler monkey & 6.46 & 101 & 15 & 4 & 0.6 & 234 & 42 & 70 & 33 & 105 & 38 \\
\hline Black lion tamarin & $0.60^{c}$ & 1 & 0.2 & 1 & 0.1 & 0.1 & 0.02 & 0.6 & 0.3 & 2 & 1 \\
\hline Total biomass & & 646 & $\%$ & 600 & $\%$ & 557 & $\%$ & 201 & $\%$ & 273 & $\%$ \\
\hline Total biomass of primates & & 137 & 21 & 65 & 10 & 263 & 47 & 100 & 49 & 142 & 52 \\
\hline Total biomass of ungulates & & 413 & 64 & 431 & 71 & 212 & 38 & 42 & 20 & 107 & 39 \\
\hline Total biomass of nonhunted species & & 137 & 21 & 69 & 11 & 270 & 49 & 102 & 50 & 143 & 52 \\
\hline Total biomass of hunted species & & 508 & 78 & 530 & 88 & 286 & 51 & 99 & 49 & 130 & 45 \\
\hline
\end{tabular}

${ }^{a}$ Mean body weights are from peccaries captured by Alexine Keuroglian at Caetetus Ecological Station $n=6$ for both species.

${ }^{b}$ Average of mean body weights of Mazama americana and M. gouazoubira taken from Robinson \& Redford (1986).

${ }^{c}$ Mean body weight estimates taken from Valladares-Padua (1993).

$\%=$ Percentage contribution to total biomass.

$\mathrm{P}=$ Present, but not seen during census.

slightly hunted site of Fazenda Mosquito had slightly lower crude biomass at $557 \mathrm{~kg}$ per sq $\mathrm{km}$. Crude biomass was considerably lower at the two heavily hunted sites with $201 \mathrm{~kg}$ per sq $\mathrm{km}$ at Fazenda Tucano and $273 \mathrm{~kg}$ per sq $\mathrm{km}$ at Fazenda Rio Claro. In the protected sites white-lipped and collared peccary had the greatest crude biomass, whereas in the slightly hunted and heavily hunted sites the primates had greater crude biomass than the peccaries. Lowland tapir biomass was greatest in the protected sites.

The crude biomass of non-hunted species varied among sites, but showed no clear trend between protected, slightly hunted and heavily hunted areas. In contrast, there was a clear negative relationship between crude biomass of hunted species and hunting pressure, with crude biomass of hunted species greatest in the protected sites, less in the slightly hunted site, and even lower in the heavily hunted sites.

\section{Metabolic biomass}

The greatest metabolic biomass of the large- and mediumsized mammals was at Morro do Diabo State Park (Table 5). At the protected Caetetus Ecological Station the metabolic biomass of the large- and medium-sized mammals was 91 per cent of Morro do Diabo State Park and at the slightly hunted Fazenda Mosquito the metabolic biomass was 95 per cent of Morro do Diabo State
Park. In contrast, the metabolic biomass of the large- and medium-sized mammals at the heavily hunted sites of Fazenda Tucano and Fazenda Rio Claro were only 38 and 48 per cent of Morro do Diabo State Park, respectively.

Ungulates dominated the metabolic biomass at the two most protected sites and made up 51 per cent at Morro do Diabo and 58 per cent at Caetetus Ecological Station, whereas ungulates at the slightly hunted and heavily hunted sites contributed less to the metabolic biomass, with only 26 per cent at Fazenda Mosquito, 15 per cent at Fazenda Tucano and 31 per cent at Fazenda Rio Claro. Primates at the two protected sites made up only 26 per cent at Morro do Diabo and 15 per cent at Caetetus Station. Conversely, primates represented more than half of the metabolic biomass at the slightly hunted and heavily hunted sites, with 52 per cent at Fazenda Mosquito, 50 per cent at Fazenda Tucano and 57 per cent at Fazenda Rio Claro. At the two protected sites, whitelipped and collared peccaries had the greatest metabolic biomass. At the slightly hunted site the brown capuchin monkeys, brown howler monkeys, nine-banded armadillos and white-lipped peccaries had the greatest metabolic biomass, whereas at the two heavily hunted sites brown capuchin monkeys, brown howler monkeys and collared peccaries had the greatest metabolic biomass.

When combined, metabolic biomass of non-hunted species had a more homogeneous distribution across all sites. Metabolic biomass of hunted species decreased 
Table 5 Metabolic biomass (MB) estimates of large- and medium-sized mammals in the five study sites of the Plateau. Values are in $\mathrm{kg}$ per sq $\mathrm{km}$.

\begin{tabular}{|c|c|c|c|c|c|c|c|c|c|c|c|}
\hline \multirow[b]{2}{*}{ Species } & \multirow{2}{*}{$\begin{array}{l}\text { Mean } \\
\text { metabolic } \\
\text { body } \\
\text { weight } \\
(\mathrm{kg})\end{array}$} & \multicolumn{2}{|c|}{$\begin{array}{l}\text { Morro do Diabo } \\
\text { State Park } \\
\text { (Protected) }\end{array}$} & \multicolumn{2}{|c|}{$\begin{array}{l}\text { Caetetus Ecolo- } \\
\text { gical Station } \\
\text { (Protected) }\end{array}$} & \multicolumn{2}{|c|}{$\begin{array}{l}\text { Fazenda Mos- } \\
\text { quito (Slighted } \\
\text { hunted) }\end{array}$} & \multicolumn{2}{|c|}{$\begin{array}{l}\text { Fazenda Tucano } \\
\text { (Heavily } \\
\text { hunted) }\end{array}$} & \multicolumn{2}{|c|}{$\begin{array}{l}\text { Fazenda Rio } \\
\text { Claro (Heavily } \\
\text { hunted) }\end{array}$} \\
\hline & & MB & $\%$ & $\mathrm{MB}$ & $\%$ & MB & $\%$ & MB & $\%$ & $\mathrm{MB}$ & $\%$ \\
\hline Lowland tapir & 42.43 & 17 & 5 & 20 & 6 & 12 & 4 & 0 & 0 & 0 & 0 \\
\hline White-lipped peccary & 13.35 & 92 & 27 & 84 & 27 & 48 & 15 & 0 & 0 & 0 & 0 \\
\hline Collared peccary & 9.10 & 51 & 15 & 58 & 19 & 7 & 2 & 20 & 15 & 51 & 31 \\
\hline Brocket deer & 10.06 & 11 & 3 & 18 & 5 & 17 & 5 & $\mathrm{P}$ & $\mathrm{P}$ & $\mathbf{P}$ & $\mathrm{P}$ \\
\hline Azara's agouti & 2.18 & 58 & 17 & $P$ & $P$ & 0.8 & 0.2 & 8 & 6 & 2 & 1 \\
\hline Nine-banded armadillo & 2.58 & 2 & 0.6 & 60 & 19 & 43 & 13 & 24 & 19 & $\mathbf{P}$ & $\mathrm{P}$ \\
\hline South American coati & 2.76 & 11 & 3 & 12 & 4 & 9 & 3 & 8 & 6 & 14 & 9 \\
\hline Guianan squirrel & 0.48 & 0.1 & 0.05 & 5 & 1 & 9 & 3 & 2 & 1 & 1 & 0.8 \\
\hline Brown capuchin monkey & 2.52 & 25 & 7 & 44 & 14 & 21 & 6 & 21 & 16 & 25 & 15 \\
\hline Brown howler monkey & 4.05 & 63 & 18 & 2.43 & 0.8 & 147 & 46 & 44 & 34 & 66 & 40 \\
\hline Black lion tamarin & 0.68 & 1.8 & 0.5 & 1.16 & 0.4 & 0.1 & 0.05 & 0.6 & 0.5 & 2 & 1.5 \\
\hline Total metabolic biomass & & 335 & $\%$ & 307 & $\%$ & 317 & $\%$ & 130 & $\%$ & 163 & $\%$ \\
\hline Total metabolic biomass of primates & & 90 & 26 & 48 & 15 & 168 & 53 & 66 & 50 & 94 & 57 \\
\hline Total metabolic biomass of ungulates & & 172 & 51 & 181 & 58 & 85 & 26 & 20 & 15 & 5 & 31 \\
\hline $\begin{array}{l}\text { Total metabolic biomass of non- } \\
\text { hunted species }\end{array}$ & & 90 & 27 & 53 & 17 & 177 & 56 & 68 & 52 & 95 & 58 \\
\hline $\begin{array}{l}\text { Total metabolic biomass of hunted } \\
\text { species }\end{array}$ & & 244 & 73 & 254 & 82 & 139 & 43 & 62 & 47 & 67 & 41 \\
\hline
\end{tabular}

$\%=$ Percentage contribution to total large- and medium-sized mammal metabolic biomass.

$\mathrm{P}=$ Present, but not seen during census.

with hunting pressure. Not surprisingly, at the slightly hunted site there was greater evenness in the relative contribution of hunted and non-hunted species. Hunting has clearly inverted the relative contribution of species to metabolic biomass, especially when ungulates and primates are considered. That is, primates dominate the metabolic biomass or relative energy consumption at hunted sites, whereas ungulates comprise the bulk of the metabolic biomass or relative energy consumption at protected sites.

\section{Discussion}

The energy consumed by mammals, as measured by metabolic biomass, in the protected sites is dominated by terrestrial ungulates and in the hunted sites by arboreal primates. This has caused an ecological inversion. The ecological consequences of this inversion should be reflected in numerous ecological interactions, including seed dispersal and seed predation, herbivory, and predator-prey interactions, among others. This suggests that hunting is changing the ecological structure at hunted sites by depriving these areas of much of the terrestrial mammalian biomass.

The ecological consequences can be seen in the ungulates, which include the lowland tapir, brocket deer and peccaries. For example, brocket deer and peccaries are important seed predators and tapirs important seed dispersers (Bodmer, 1989; Fragoso, 1998). The seed predators can alter the survival rates of fruit-producing trees, whereas the seed dispersers can transport seeds away from the mother tree and enhance seed recruitment and survival. Ungulates are probably important 'engineers' in affecting forest composition and structure, and their depletion by hunting could lead to community changes in hunted forest fragments. This is especially true for the white-lipped peccary, because of its larger group size (Fragoso, 1998; Painter, 1998).

Palm trees are an important and sometimes key resource for peccaries in the Neotropics (Bodmer, 1991; Fragoso, 1998). The palm tree Syagrus romanzofianna is very common throughout the Plateau range. This palm species might explain the high densities of white-lipped peccaries in the Plateau area. Syagrus romanzofianna has densities of around 20 individuals per hectare and occurs either as isolated individuals or clumps (Lorenzi, 1992). These palms produce hundreds to thousands of fruits, each averaging $2.5 \times 1.5 \mathrm{~cm}$ and with bright yellow, sweet, and fibrous pericarp (Sanchotene, 1985; Olmos et al., 1999). Syagrus romanzofianna produces fruits all year around and might be a key resource for the white-lipped peccary during periods when other fruits are less available. Indeed, during the dry season herds of white-lipped peccaries are frequently encountered under clumps of S. romanzofianna (L. Cullen, pers. observ.). The large herd size and the aggressive behaviour of white-lipped 
peccaries could give them a competitive advantage during feeding interactions with other species.

\section{Hunting and biomass inversions}

In the Plateau, hunting is carried out mainly by colonists who encroach on forest fragments. Results of this study suggest that hunting is probably the main process altering the ecological relationships within fragments and causing an ecological inversion of mammalian biomass in forest fragments surrounded by humans. It is widely known that numerous proximate fragmentation factors can affect small and fragmented animal populations (Lawton, 1995). Hunting, however, clearly prevails over these proximate factors and seems to be the ultimate factor responsible for the extirpation of large- and medium-sized mammals from forest fragments and, in turn, altering ecological relationships.

The impact of hunting on the mammalian community structure in the Plateau forests differs from other Neotropical sites. In many Neotropical areas hunting is more evenly distributed among primates, large rodents and ungulates (Bodmer et al., 1997; Alvard, 1998; Peres, 2000) than in the Plateau forest where hunting concentrates heavily on ungulates. Indeed, in Amazonian sites where primates are frequently hunted, the impact of hunting is opposite to what we found in the Plateau forests. In Amazonian forests, primate biomass is greatly reduced and peccary, deer and large rodent biomass does not change much between nonhunted vs. hunted sites (Bodmer et al., 1997; Alvard, 1998). Both the Plateau region and Amazonia show biomass inversions as a result of hunting, but in completely different directions, with ungulate biomass being reduced in hunted Plataeu forests and primate biomass being reduced in hunted Amazonian forests.

\section{Implications for conservation}

Hunting in forest fragments of the Atlantic forests is currently illegal. However, recent legislation will set the stage for legalizing hunting under a series of management controls. This will allow people to hunt legally if the hunting is sustainable and has been authorized by appropriate officials. Studies such as this one can help government authorities evaluate the impact of hunting in forest fragments. Hunting in small forest fragments can be detrimental to the wildlife and the ecosystem's functions. Alternatives to hunting clearly need to be found to manage the remaining forest fragments in a manner consistent with conservation.

Plateau forests are probably the most fragmented and most threatened ecosystem within the Atlantic forests. They harbour a rich flora and fauna with many endemic and endangered species. Biologically these fragments are highly valued because they represent the last remaining 'seeds' of the endangered Atlantic forest ecosystem. Future conservation measures will have to take a metapopulation approach along with eco-regional planning.

\section{Acknowledgements}

This study was funded by a collection of small grants including the Scott Neotropical Fund of Lincoln Park Zoological Society; the Tropical Conservation and Development Program (TCD) of University of Florida; the Tinker Foundation; the Biodiversity Support Program, a consortium between US AID, World Wildlife Fund/US, The Nature Conservancy, and the World Resources Institute; The Conservation, Food and Health Foundation; the Programa Natureza e Sociedade World Wildlife Fund - Brazil; Fauna and Flora International's 100 per cent Fund; Duratex Company; and the Smithsonian Institution/US. Institutional support was provided by IPÊ - Instituto de Pesquisas Ecológicas and the Instituto Florestal de São Paulo, IF-SMA.

\section{References}

Ab'Saber, A.N. (1977) Os domínios morfoclimáticos da América do Sul. Geomorfologia, 52, 1-23.

Alvard, M. (1998) Indigenous hunting in the Neotropics: conservation or optimal foraging? In Behavioral Ecology and Conservation Biology (ed. T. M. Caro), pp. 474-500. Oxford University Press, Oxford.

Baitello, J.B., Pastore, J.A., Aguiar, O.T., Serio, F.C. \& Silva, C.E. (1988) A vegetação do Parque Estadual do Morro do Diabo, município de Teodoro Sampaio, Estado de São Paulo. Acta Botânica Brasileira, 1, 221-230.

Bodmer, R.E. (1989) Frugivory in Amazonian artiodactyla: evidence for the evolution of the ruminant stomach. Journal of Zoology, 219, 457-467.

Bodmer, R.E. (1991) Strategies of seed dispersal and seed predation in Amazonian ungulates. Biotropica, 23, 255-261.

Bodmer, R.E., Eisenberg, J.F. \& Redford, K.H. (1997) Hunting and the likelihood of extinction of Amazonian mammals. Conservation Biology, 11, 460-466.

Buckland, S.T., Anderson, D.R., Burnham, K.P. \& Laake, J.L. (1993) DISTANCE Sampling: Estimating Abundance of Biological Populations. Chapman \& Hall, London.

Burnham, K.P., Anderson, D.R. \& Laake, J.L. (1980) Estimation of density from line transect sampling of biological populations. Wildlife Monographs, 72, 202.

Cullen, L. Jr (1997) Hunting and biodiversity in Atlantic forest fragments, São Paulo, Brazil. MSc Thesis, University of Florida, Florida, USA.

Cullen, L. Jr., Bodmer, R.E. \& Valladares-Padua, C. (2000) Effects of hunting in habitat fragments of the Atlantic forests, Brazil. Biological Conservation, 95, 49-56. 
Eisenberg, J.F. (1980) The density and biomass of tropical mammals. In Conservation Biology, an Evolutionary-Ecological Perspective (eds M. E. Soule and B. A. Wilcox), pp. 35-55. Sinauer Press, Sunderland.

Eisenberg, J.F., O'Connell, M.A. \& August, P.V. (1979) Density, productivity, and distribution of mammals in two Venezuelan habitats. In Vertebrate Ecology in the Northern Neotropics (ed. J. F. Eisenberg), pp. 187-207. Smithsonian Institution Press, Washington, DC.

Eisenberg, J.F. \& Thorington, R.W. (1973) A preliminary analysis of a Neotropical mammal fauna. Biotropica, 5 , 150-161.

Emmons, L.H. (1984) Geographic variation in densities and diversities of non-flying mammals in Amazonia. Biotropica, 16, 210-222.

Fragoso, J.M. (1998) Home range and movement patterns of white-lipped peccary (Tayassu pecari) herds in the northern Brazilian Amazon. Biotropica, 30, 458-469.

Glanz, W.E. (1982) The terrestrial mammal fauna of Barro Colorado Island: censuses and long-term changes. In The Ecology of a Tropical Forest (eds E. G. Leigh, A. S. Rand and D. M. Windsor), pp. 455-468. Smithsonian Institution Press, Washington, DC.

Hill, K. \& Padwe, J. (2000) Sustainability of Aché hunting in the Mbaracayu Reserve, Paraguay. In Hunting for Sustainability in Tropical Forests (eds J. G. Robinson and E. L. Bennett), pp. 79 105. Columbia University Press, New York.

Hueck, K. (1972) As florestas da América do Sul. Editora Polígono e Editora Universidade de Brasilia, São Paulo, Brasilia.

Janson, C.H. \& Emmons. L.H. (1990) Ecological structure of the non-flying mammal community at Cocha Cachu Biological Station, Manu National Park, Peru. In Four Neotropical Rainforests (ed. A. H. Gentry), pp. 314-338. Yale University Press, New Haven, USA.

Laake, J.L., Buckland, S.T., Anderson, D.R. \& Burnham, K.P. (1994) DISTANCE User's Guide. Colorado Cooperative Fish and Wildlife Service, Fort Colins, Colorado, USA.

Lawton, J.H. (1995) Population dynamic principles. In Extinction Rates (eds J. H. Lawton and R. M. May), pp. 147-163. Oxford University Press, Oxford.

Lorenzi, H. (1992) Árvores Brasileiras: Manual de indentificação e cultivo de plantas arbóreas do Brasil. Editora Plantarium, Nova Odessa.

Olmos, F., Pardini, R., Boulhosa, R.L.P., Bürgi, R. \& Morsello, C. (1999) Do tapirs steal food from palm seed predators or give them a lift? Biotropica, 31, 375-379.

Painter, R.L.E. (1998) Gardeners of the forest: plant-animal interactions in a neotropical forest ungulate community. PhD Dissertation, University of Liverpool, Liverpool, UK.

Peres, C.A. (1990) Effects of hunting on western Amazonian primate communities. Biological Conservation, 53, 47-59.

Peres, C.A. (2000) Evaluating the impact and sustainability of subsistence hunting at multiple Amazonian forest sites. In Hunting for Sustainability in Tropical Forests (eds J. G. Robinson and E. L. Bennett), pp. 31-56. Columbia University Press, New York.

Peters, R.H. (1983) The Ecological Consequences of Body Size. Cambridge University Press, New York.

Robinson, J.G. \& Redford, K.H. (1986) Body size, diet and population density of neotropical forest mammals. American Naturalist, 128, 665-680.
Sanchotene, M.C.C. (1985) Frutiferas nativas úteis a fauna na arborização urbana. Editora FEPLAM, Porto Alegre, Brasil.

Schaller, G.B. (1983) Mammals and their biomass on a Brazilian ranch. Arquivos de Zoologia, 3, 1-36.

Setzer, J. (1949) Os solos do Estado de São Paulo, 1st edn. Conselho Nacional de Geografia, Rio de Janeiro.

Terborgh, J.W. (1988) The big things that run the world - a sequel to E. O. Wilson. Conservation Biology, 2, 402-403.

Valladares-Padua, C. (1987) Black lion tamarin (Leontopithecus chrysopygus): status and conservation. MSc Thesis. University of Florida, FL, USA.

Valladares-Padua, C. (1993) The ecology, behavior and conservation of the black lion tamarins (Leontopithecus chrysopygus, Mikan, 1823). PhD Dissertation, University of Florida, Florida, USA.

Valladares-Padua, C. \& Cullen, L. Jr (1992) Unpublished Report to the Primate Project Coordination: Duraflora. Lençois Paulista, Spain.

Wilson, D.E., Cole, F.R., Nichols, J.D., Rudran, R. \& Foster, M.S. (1996) Measuring and Monitoring Biological Diversity. Standard Methods for Mammals. Smithsonian Institution Press, Washington, DC.

\section{Biographical sketches}

Richard Bodmer joined the Durrell Institute of Conservation and Ecology (DICE) at the University of Kent in August 2000 as a Lecturer in Biodiversity Conservation. His doctoral research at Cambridge was on plant-animal interactions of Amazonian ungulates and his post-doctoral research at the Museu Goeldi, Brazil was on sustainable resource use. Since 1993 he has had a position in the Tropical Conservation and Development Program at the University of Florida where his research focused on the biology, conservation and sustainable use of Amazonian wildlife. He has also done research in the rain forests of central Africa and Borneo.

Laury Cullen Junior is a Conservation Biologist and Research Coordinator with IPE - Institute for Ecological Research - an NGO based in the state of São Paulo, Brazil. He received his MSc from the University of Florida in 1997. His main interests are the ecology and conservation of large mammals in the Atlantic Forest, particularly using large and umbrella species as landscape indicators for eco-regional planning.

Claudio Valladares Padua gained his $\mathrm{PhD}$ from the University of Florida in 1993. He is a cofounder of IPE where he works as Director of Conservation Science. He is also a Professor at the University of Brasília and senior researcher with the Wildlife Trust. Claudio Padua has recently received the Henry Ford Award for Conservation, the Whitley Continuation Award of the Royal Geographic Society, and the Society for Conservation Biology Achievement Award. In addition, he has edited two books and has more than 40 articles published in national and international journals or book chapters. 